\title{
Progressive cyanosis following Kawashima operation: slow resolution after redirection of hepatic veins
}

\author{
Signe Holm Larsen ${ }^{1,3^{*}}$, Kristian Emmertsen ${ }^{1}$, Jesper Bjerre ${ }^{2}$ and Vibeke Elisabeth Hjortdal ${ }^{3}$
}

\begin{abstract}
Progressive cyanosis often develops following Kawashima operation in patients with left atrial isomerism, interrupted inferior vena cava and hepatic veins draining to the atria. Knowledge on the timing and extend of resolution following hepatic venous redirection is sparse. A girl developed progressing cyanosis following Kawashima operation at the age of ten months. Arterial oxygen saturations at rest dropped to $60-65 \%$. Surgical redirection of hepatic veins into the cavopulmonary circulation at the age of three years had no immediate effect. However, arterial oxygen saturations increased gradually over nine months to $90-93 \%$ and $95-100 \%$ after three years.
\end{abstract}

Keywords: Congenital heart surgery, Pulmonary arteriovenous malformations, Fontan, Left atrial isomerism

\section{Background}

Patients with functional univentricular hearts, left atrial isomerism and azygos continuation of the inferior vena cava are usually surgically palliated by cavopulmonary anastomosis between one or two superior vena cavas to the pulmonary artery, the Kawashima operation. The hepatic veins remain connected to one or both left atria and thus to the systemic circulation, which in itself will cause some arterial desaturation. However, in many patients arterial desaturation is progressive causing cyanosis and functional limitation. When veno-venous collaterals from the systemic to the hepatic veins are excluded, progressive cyanosis is attributed to development of multiple microscopic pulmonary arteriovenous malformations [1,2]. It is hypothesized that one or more unknown hepatic factors from the hepatic circulation need to flow directly to the pulmonary circulation in order to suppress a genuine tendency to develop arteriovenous malformations in the lungs [3,4]. A recent study [5] suggests that inhibition of endostatin may play an important role in increased angiogenesis and formation of arteriovenous malformations. Several reports

\footnotetext{
* Correspondence: signe_holm_larsen@hotmail.com

'Department of Cardiology, Aarhus University Hospital, Brendstrupgaardsvej, 8200 Aarhus N, Denmark

${ }^{3}$ Department of Cardiothoracic surgery, Aarhus University Hospital, Brendstrupgaardsvej, 8200 Aarhus N, Denmark

Full list of author information is available at the end of the article
}

[6-9] indicate that cyanosis resolves following surgical redirection of hepatic veins into the cavopulmonary circulation. This operation is usually performed through a median sternotomy using cardiopulmonary bypass. However, an off-pump technique through a lateral thoracotomy has been described [10]. The literature on the timing and extent of resolution following redirection of the hepatic veins is sparse.

In order to demonstrate this may be a lengthy process, we report our experience of redirecting hepatic flow in a patient with left atrial isomerism and review the current literature.

\section{Case presentation}

A newborn girl was diagnosed with dextrocardia, left atrial isomerism, azygous continuation to a solitary left sided superior vena cava, hepatic veins draining to the left sided atrium, unbalanced atrioventricular septal defect, double outlet right ventricle and valvar pulmonary stenosis. Initially the patient was surgically palliated with an aortopulmonary shunt. Kawashima operation with closure of the shunt was performed at the age of ten months. Postoperatively resting saturations were initially $85-90 \%$, but declined over the next two years to $60-65 \%$. Cardiac catheterization showed an unobstructed leftsided cavopulmonary anastomosis, low pulmonary artery pressures and absence of significant veno-venous 
collaterals. No macroscopic arteriovenous malformations were present. At the age of three years, the hepatic veins were excised from the atrium with a cuff of atrial tissue, anastomosed to a GORE-TEX ${ }^{\circledR}$ tube graft which was placed along the left side of the heart and anastomosed end-to-side to the confluent pulmonary arteries facing the superior cavopulmonary connection. The operation was done through a median sternotomy using cardiopulmonary bypass on beating heart. Postoperatively oxygen saturations were initially $60-70 \%$ but increased to approximately $85 \%$ after four weeks, $90-93 \%$ after nine months and $95-100 \%$ after three years, when she was last seen.

Pulmonary arteriovenous malformations are a common finding following the classic cavopulmonary shunt i.e. superior vena cava to right pulmonary artery [11]. However, the prevalence following total cavopulmonary connection (TCPC) has been described as relatively low $[12,13]$, except for patients with left atrial isomerism in whom the hepatic venous flow is not incorporated directly in the TCPC. In these patients pulmonary arteriovenous malformations develops in 21-75 percent $[3,7,9,14]$. The large range in patients developing pulmonary arteriovenous malformations may be a combination of lack of early awareness of the problem, a wide range in the clinical presentation, additional venous-venous collaterals and a time factor, since these malformations take several years to develop. Table 1 shows a summary of the current literature with focus on the timing of surgical redirection of hepatic venous flow and time to resolution.
The development and diagnosis of pulmonary arteriovenous malformations following the Kawashima operation usually takes several years $[4,6,9,13,15-20]$, but has been described after a few days [21]. Pulmonary arteriovenous malformations are usually diagnosed when oxygen saturations are between 65 and $76 \%$ $[4,9,13,15-18]$.

Most studies report that pulmonary arteriovenous malformations resolve slowly following surgical redirection of the hepatic flow. Resting oxygen saturations as low as $70-85 \%$ for months after the operation are common $[4,6,13,15,17,18]$. In general, the saturations improve over time. Studies with a follow-up of several months to a few years report saturations between 93 and $97 \%[8,9,15,17,18,20,22]$. Saturations remaining at $85-90$ $\%$ have been described $[4,13]$. Timing of redirection of hepatic flow remains controversial. A recent study [22] indicates that the majority of patients will need redirection of hepatic flow following the Kawashima operation, in particular when followed beyond 60 months. Furthermore, there was an indication that worse outcome was related to profound desaturation before redirection, indicating a benefit of an earlier redirection [22].

\section{Conclusions}

In patients with left atrial isomerism pulmonary arteriovenous malformations should be considered when the hepatic flow has not been included in the TCPC and saturations start to decline. Following surgical inclusion of hepatic veins recovery may take several months to occur.

Table 1 Summary of the current literature of arterial oxygen saturations following redirection of hepatic venous flow in Kawashima patients

\begin{tabular}{|c|c|c|c|c|c|}
\hline Study & $\mathbf{N}$ & $\begin{array}{l}\text { Time from Kawashima to diagnosis/ } \\
\text { redirection of PAVMs }\end{array}$ & $\begin{array}{l}\text { Saturation at } \\
\text { diagnosis }\end{array}$ & $\begin{array}{l}\text { Saturation at early follow-up } \\
\text { (follow-up time) }\end{array}$ & $\begin{array}{l}\text { Saturation at last follow-up } \\
\text { (follow-up time) }\end{array}$ \\
\hline Aidala [4]* & 1 & 3 years & $65 \%$ & $70 \%$ at discharge & $85 \%$ (1 year) \\
\hline Baskett [15] & 1 & $\approx 3$ years & $71 \%$ & $60-80 \%$ & $92 \%$ (6 months) \\
\hline Brown [9] & $11^{* *}$ & $5.7 \pm 3.1$ years $(2-11) \dagger$ & $75 \%(64-85 \%) \neq$ & ND & $\begin{array}{l}95 \pm 2 \%(93-98) \dagger \\
(4.1 \pm 2.3 \text { years }(1-7))+\end{array}$ \\
\hline Knight [16] & 1 & 25 months & $65-70 \%$ & $70 \%$ & 96\% (13 months) \\
\hline Kutty [19] & 13 & 2.61 years $(0.61-7.35) \neq$ & $76 \%(70-82 \%) \dagger$ & ND & $88.7 \pm 7.6 \% \dagger$ \\
\hline Latson [20] & 1 & $\approx 14$ years & $50 \%$ & 80\% (day of operation) & >93\% (2 years) \\
\hline McElhinney [6] & 16 & 3.1 years ( 6 months -10 years) $\neq$ & $76 \%(65-85 \%) \neq \S$ & $76 \pm 8 \%$ (1 week-12 months) $+\S$ & $\begin{array}{l}90 \pm 9 \%+(6.3 \text { years } \\
(2.8-10 \text { years })) \neq\end{array}$ \\
\hline Pandurangi [21] & 1 & 72 hours & $40-60 \% \S$ & $85 \% \|$ & 85\% \|(48 hours) \\
\hline Pike [17] & 1 & $\approx 2$ years & $68-70 \%$ & 75\% (4th day), 85\% (3 weeks) & $\begin{array}{l}94 \% \text { (7 weeks), 93-94\% } \\
\text { (7 months) }\end{array}$ \\
\hline Shah [8] & 3 & 8 months $(7-27) \neq$ & ND & Range $80-84 \%$ (7-10 days) & >92\% (7-12 months) \\
\hline Shinohara [13] & 1 & 5 years and 9 months & $75 \%$ & 70\% (1 month), 80 (0.5 years) & $90 \%$ (2 years) \\
\hline
\end{tabular}

$\mathrm{N}$ : Number of patients, ND: Not Described,

*Partial redirection of the hepatic veins, ${ }^{* * 10}$ patients operated (nine evaluated for PAVMs), †Mean \pm standard deviation (range),

¥Median (range), §Systemic arterial oxygen saturation, || dies 48 hours after operation 


\section{Consent}

Written informed consent was obtained from the family of patient for publication of this Case report. A copy of the written consent is available for review by the Editorin-Chief of this journal.

\section{Competing interests}

The authors declare that they have no competing interests.

\section{Authors' contributions}

SHL: concept/design, interpretation, drafting article, critical revision of article, approval of article. KE: concept/design, interpretation, critical revision of article, approval of article. JB: concept/design, critical revision of article, approval of article. VEH: concept/design, interpretation, critical revision of article, approval of article. All authors read and approved the final manuscript.

\section{Author details}

'Department of Cardiology, Aarhus University Hospital, Brendstrupgaardsvej, 8200 Aarhus N, Denmark. ²Department of Pediatrics, Aarhus University Hospital, Brendstrupgaardsvej, 8200 Aarhus N, Denmark. ${ }^{3}$ Department of Cardiothoracic surgery, Aarhus University Hospital, Brendstrupgaardsvej, 8200 Aarhus N, Denmark.

Received: 30 January 2013 Accepted: 21 March 2013

Published: 5 April 2013

\section{References}

1. Duncan BW, Kneebone JM, Chi EY, Hraska V, Isik FF, Rosenthal GL, Jones TK, Starnes SL, Lupinetti FM: A detailed histologic analysis of pulmonary arteriovenous malformations in children with cyanotic congenital heart disease. J Thorac Cardiovasc Surg 1999, 117(5):931-938.

2. Starnes SL, Duncan BW, Kneebone JM, Fraga CH, States S, Rosenthal GL, Lupinetti FM: Pulmonary microvessel density is a marker of angiogenesis in children after cavopulmonary anastomosis. J Thorac Cardiovasc Surg 2000, 120(5):902-907.

3. Srivastava D, Preminger T, Lock JE, Mandell V, Keane JF, Mayer JE Jr, Kozakewich H, Spevak PJ: Hepatic venous blood and the development of pulmonary arteriovenous malformations in congenital heart disease. Circulation 1995, 92(5):1217-1222.

4. Aidala E, Chiappa E, Cascarano MT, Valori A, Abbruzzese PA: Partial hepatic vein diversion in pulmonary arteriovenous malformations in congenital heart disease. Ann Thorac Surg 2004, 78(3):1089-1090.

5. Field-Ridley A, Heljasvaara R, Pihlajaniemi T, Adatia I, Sun C, Keller RL, Gong WH, Datar S, Oishi P, Fineman JR: Endostatin, an Inhibitor of Angiogenesis, Decreases After Bidirectional Superior Cavopulmonary Anastamosis. Pediatr Cardiol 2013, 34(2):291-295.

6. McElhinney DB, Kreutzer J, Lang P, Mayer JE Jr, del Nido PJ, Lock JE: Incorporation of the hepatic veins into the cavopulmonary circulation in patients with heterotaxy and pulmonary arteriovenous malformations after a Kawashima procedure. Ann Thorac Surg 2005, 80(5):1597-1603.

7. Mahmoud AB, Zahrani S, Bahaidarah SA, Kouatli AA, Baslaim GM: Venovenous malformation: a common finding after Kawashima operation. EJCTS: official journal of the European Association for Cardio-thoracic Surgery 2011, 39(2):222-227.

8. Shah MJ, Rychik J, Fogel MA, Murphy JD, Jacobs ML: Pulmonary AV malformations after superior cavopulmonary connection: resolution after inclusion of hepatic veins in the pulmonary circulation. Ann Thorac Surg 1997, 63(4):960-963.

9. Brown JW, Ruzmetov M, Vijay P, Rodefeld MD, Turrentine MW: Pulmonary arteriovenous malformations in children after the Kawashima operation. Ann Thorac Surg 2005, 80(5):1592-1596.

10. Lopez FE, van den Heuvel F, Pieper PG, Waterbolk TW, Ebels T: Off-pump connection of the hepatic to the azygos vein through a lateral thoracotomy for relief of arterio-venous fistulas after a Kawashima procedure. Cardiol Young 2008, 18(3):311-315.

11. Cloutier A, Ash JM, Smallhorn JF, Williams WG, Trusler GA, Rowe RD, Rabinovitch M: Abnormal distribution of pulmonary blood flow after the Glenn shunt or Fontan procedure: risk of development of arteriovenous fistulae. Circulation 1985, 72(3):471-479.
12. Amodeo A, Marino B: Pulmonary arteriovenous fistulas in patients with left isomerism and cardiac malformations. Cardiol Young 1998, 8(3):283-284.

13. Shinohara T, Yokoyama T: Pulmonary arteriovenous malformation in patients with total cavopulmonary shunt: what role does lack of hepatic venous blood flow to the lungs play? Pediatr Cardiol 2001, 22(4):343-346.

14. McElhinney DB, Marx GR, Newburger JW: Congenital portosystemic venous connections and other abdominal venous abnormalities in patients with polysplenia and functionally univentricular heart disease: a case series and literature review. Congenit Hear Dis 2011, 6(1):28-40.

15. Baskett RJ, Ross DB, Warren AE, Sharratt GP, Murphy DA: Hepatic vein to the azygous vein anastomosis for pulmonary arteriovenous fistulae. Ann Thorac Surg 1999, 68(1):232-233.

16. Knight WB, Mee RB: A cure for pulmonary arteriovenous fistulas? Ann Thorac Surg 1995, 59(4):999-1001.

17. Pike NA, Vricella LA, Feinstein JA, Black MD, Reitz BA: Regression of severe pulmonary arteriovenous malformations after Fontan revision and "hepatic factor" rerouting. Ann Thorac Surg 2004, 78(2):697-699.

18. Imoto $Y$, Sese A, Joh K: Redirection of the hepatic venous flow for the treatment of pulmonary arteriovenous malformations after Fontan operation. Pediatr Cardiol 2006, 27(4):490-492.

19. Kutty S, Frommelt MA, Danford DA, Tweddell JS: Medium-term outcomes of Kawashima and completion Fontan palliation in single-ventricle heart disease with heterotaxy and interrupted inferior vena cava. Ann Thorac Surg 2010, 90(5):1609-1613.

20. Latson LA, Mumtaz MA: Cyanosis after Kawashima-Fontan: hybrid approach to mixing and matching flows. Ann Thorac Surg 2011 92(4):e81-e83.

21. Pandurangi UM, Shah MJ, Murali R, Cherian KM: Rapid onset of pulmonary arteriovenous malformations after cavopulmonary anastomosis. Ann Thorac Surg 1999, 68(1):237-239.

22. Vollebregt A, Pushparajah K, Rizvi M, Hoschtitzky A, Anderson D, Austin C, Tibby SM, Simpson J: Outcomes following the Kawashima procedure for single-ventricle palliation in left atrial isomerism. EJCTS: official journal of the European Association for Cardio-thoracic Surgery 2012, 41(3):574-579.

doi:10.1186/1749-8090-8-67

Cite this article as: Larsen et al:: Progressive cyanosis following

Kawashima operation: slow resolution after redirection of hepatic veins. Journal of Cardiothoracic Surgery 2013 8:67.

\section{Submit your next manuscript to BioMed Central and take full advantage of:}

- Convenient online submission

- Thorough peer review

- No space constraints or color figure charges

- Immediate publication on acceptance

- Inclusion in PubMed, CAS, Scopus and Google Scholar

- Research which is freely available for redistribution 